\title{
Stratigraphic architecture of the Upper Cretaceous and Cenozoic along the southern border of the North Sea Basin in Belgium
}

\author{
N. Vandenberghe ${ }^{1}$, S. Van Simaeys ${ }^{1}$, E. Steurbaut ${ }^{2,1}$, J.W.M. Jagt ${ }^{3}$ \\ \& P. J. Felder ${ }^{3}$ \\ 1 Historical Geology, Redingenstraat 16, B-3000 Leuven, Belgium. \\ E-mail: noel.vandenberghe@geo.kuleuven.ac.be (corresponding author) \\ 2 Royal Belgian Institute of Natural Sciences, Vautierstraat 29, B-1000 Brussels, Belgium \\ 3 Natuurhistorisch Museum Maastricht, De Bosquetplein 6, NL-6211 KJ Maastricht, \\ The Netherlands
}

Manuscript received: February 2004; accepted: August 2004

\begin{abstract}
The Late Cretaceous and Cenozoic sedimentary record in the Campine Basin along the southern border of the North Sea Basin is analysed in terms of sequence stratigraphy. All available biostratigraphic, and in some cases, magnetostratigraphic data are used to constrain the sequence chronostratigraphy. The relative geographic extent of the strata is used as an indication of the relative sea level. Tectonic and eustatic components could be distinguished in several cases using regional geological information. Generally, sequences consist of transgressive and highstand systems tracts only and have flat, abrasiontype lower boundaries. Lowstand deposits are only identified as infill of erosional space, which generally implies marked tectonic uplift. Several eustatic and tectonic events can be correlated with similar events known elsewhere in the North Sea Basin. The time intervals spanned by the different sequences vary considerably, pointing out different control mechanisms.
\end{abstract}

Keywords: Sequence stratigraphy, North Sea Basin, Late Cretaceous, Cenozoic

\section{Introduction}

The study area is situated at the southern part of the North Sea Basin, mainly in northern Belgium (Fig. 1). For a large portion the sediments fill the Campine Basin, a subsiding area north of the Caledonian London-Brabant Massif (Wouters \& Vandenberghe, 1994; Langenaeker, 2000). Major North Sea-related subsidence, especially north of the London-Brabant Massif in the Campine Basin, resumed in the Late Cretaceous.

The area is historically well studied. Generally, the facies are shallow-water and arranged in a cyclic stratigraphical pattern (Rutot, 1883; Gullentops, 1963) quite similar to the cyclostratigraphic history of the deeperwater sections in the North Sea (Neal, 1996; Neal et al., 1998). The cyclic strata patterns are additionally discussed in terms of sequence-stratigraphic concepts.
The analysis presented below starts with the Santonian, when subsidence resumed in the Campine Basin, and ends in the Pliocene. Cenozoic sequence stratigraphy was already discussed in detail by Vandenberghe et al. (1998) and the reader is referred to this earlier work for details; in the present contribution some major new data are added.

\section{The Santonian and Campanian (Fig. 2)}

After an extended period of mainly emersion, marine sedimentation resumed over the Brabant Massif in the Cretaceous. South of the Brabant Massif axis, the clastic Lower Cretaceous Wealden facies constitute the first sediments over the Palaeozoic basement, the first marl and chalk sedimentation did not start until the beginning of the Late Cretaceous. North of the Brabant Massif, the land area was inundated only 
during the Late Santonian, in the northeast forming coastal clastic deposits in three consecutive pulses (Hergenrath Clay, Aachen Sand, Hauset Sand) (Albers \& Felder, 1979). Glauconitic clay (Lonzée) of the same age also occurs on top of the Brabant Massif (Robaszynski et al., 2002), and simultaneously chalk sedimentation took place in the Knokke area (Bal \& Verbeek, 1990) and marine facies developed in the Limburg Campine area (Jagt et al., 1995). The detrital sediments are derived from an inverted Roer Valley Graben (RVG) area (Wouters \& Vandenberghe, 1994). The clastic sedimentation in the northeast of the
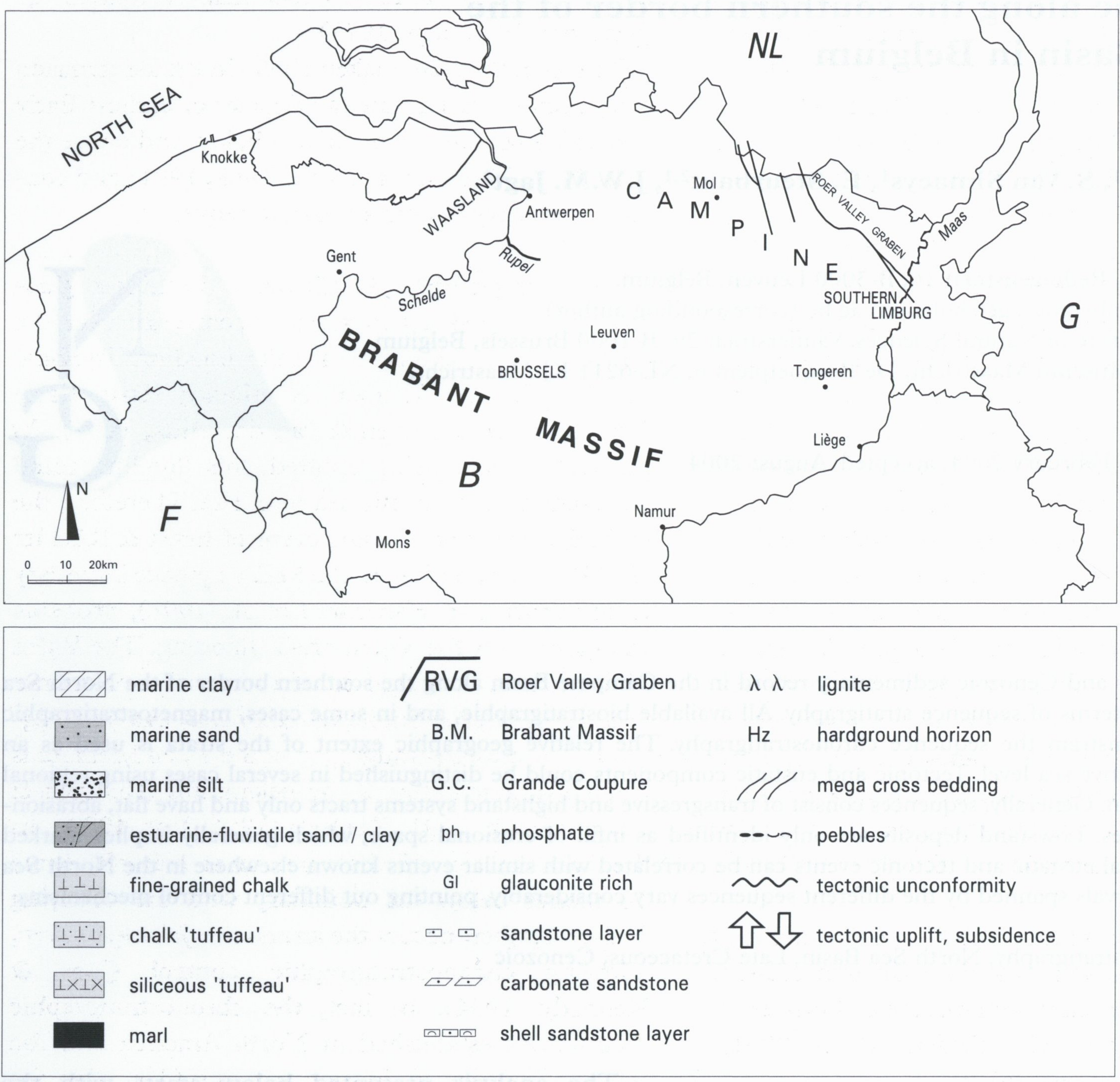

SEQUENCE BOUNDARY TYPE

- base of sequence : flat abrasion surface, pebbles,

often glauconitic greensand

- no LST ( SB = TS )

- sequence tops often bioturbated

— poorly expressed sequence boundaries in marine clayey sediments

- - sequences with a LST in a broad undeep erosional space (erosional unconformity)

deeply incised $(>50 \mathrm{~m}$ ) lower sequence boundary (erosional unconformity)

$[$ reworking

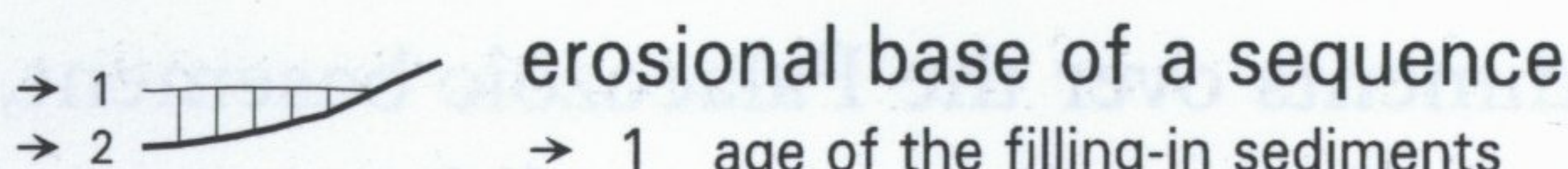

$\rightarrow 1$ age of the filling-in sediments

$\rightarrow 2$ schematic representation of the eroded thickness

Fig. 1. Location map of the study area and symbols used in Figs. 2 to 5. 
Brabant Massif continues with the Lower Campanian cyclic glauconitic Vaals Formation (Albers \& Felder, 1979). In this Formation several members have been distinguished but in fact more cycles can be observed on the lithologs (see e.g. Felder \& Bosch, 2001, Fig. 3.12). Simultaneously, chalk was deposited south of the Brabant Massif (Mons Basin) and in the northwest of the Massif (Knokke well) (Bal \& Verbeek, 1990). The detrital Vaals sediments, and the Herve smectite facies of lingualquadrata Zone which is coeval with the middle part of the Vaals Formation (Jagt, 1999), are derived from an uplifted RVG (Wouters \& Vandenberghe, 1994).

The Zeven Wegen white chalks overlie earlier siliciclastic deposits. Coeval siliciclastics are known as the Benzenrade Member of the Vaals Formation (Jagt, 1999; Felder \& Bosch, 2001). Therefore, this chalk deposit represents an important transgressive phase, also shown by its glauconitic base. A significant hiatus occurs between the Lower Campanian sequence and the Zeven Wegen-Benzenrade sequence. The base of the Zeven Wegen Member corresponds to the transgressive pulse of the conica/mucronata Zone (Late Campanian) (Keutgen \& Jagt, 1999). In the chalk column penetrated in the Knokke well, there is a hiatus corresponding to the Quadrum gothicum Zone, with chalk sedimentation above resuming in the Quadrum trifidum Zone and containing both Reinhardtites levis and $R$. anthophorus (Bal \& Verbeek, 1990). Therefore, about $25 \mathrm{~m}$ of chalk from the Knokke well corresponds to the Zeven Wegen Member.

In view of the fact that tectonic inversion uplift of the RVG was still active at that time, the transgressive occurrence of the Zeven Wegen marine carbonates, in a relatively far-offshore facies (Felder \& Bosch, 2001), points to an absolute sea-level rise.

In Fig. 2, the different cycles are drawn on a sequence-chronostratigraphic chart (Hardenbol et al., 1998, chart 5) using belemnite and nannoplankton biostratigraphic data (Albers \& Felder, 1979; Bal \& Verbeek, 1990; Robaszynski et al., 2002).

\section{The Late Campanian, Maastrichtian and Danian chalks (Figs. 2, 3)}

In the fine-grained sequence of the Campine Basin, resting on the Zeven Wegen Chalk, are found in stratigraphic order the Beutenaken, Vijlen, Lixhe and Lanaye members (Felder \& Bosch, 2001).

The basal layer of the Beutenaken chalk contains glauconite, small pebbles of quartz, Palaeozoic chert and phosphatic fossil fragments (Felder \& Bosch, 2001) indicating a transgression after tectonic uplift.
Tectonic uplift is also demonstrated by a major geometric unconformity at the top of the Zeven Wegen Chalk (Felder \& Bosch, 2001, fig 3.3).

In the Campine area, the Beutenaken Member consists of at least two lithological subunits (Felder et al., 1985) and is latest Late Campanian (Keutgen \& van der Tuuk, 1991) and in part also Maastrichtian in age (Keutgen, 1996; Jagt, 1999).

On top of the Beutenaken chalk, in the Beutenaken area, occurs a belemnite lag deposit of earliest Early Maastrichtian age, with a hiatus below and above the belemnites (Keutgen \& van der Tuuk, 1991) and consequently it represents a separate sequence.

The younger Vijlen Chalk has a diachronic glauconitic base and a widespread occurrence over the unconformity, pointing to a major flooding. The base of the Vijlen Member is already late Early Maastrichtian (Keutgen \& van der Tuuk, 1991). As the RVG is still being uplifted, this flooding could represent a new eustatic sea-level rise. Therefore, the mid-Maastrichtian eustatic event of Ernst \& Küchler (1994), corresponding to the Ma2 sequence boundary (using chart 1 of Hardenbol et al., 1998), probably coincides with the Vijlen chalk flooding. The Vijlen Member itself is composed of a succession of thinner cycles and seven subunits systematically can be recognised. The chronostratigraphy of the Vijlen Member is well constrained (Fig. 2) by belemnites (Keutgen \& van der Tuuk, 1991; Keutgen, 1996; Jagt, 1999). In the basal metres of the uppermost subunit, some 10 metres below the boundary with the overlying Lixhe Member, occurs the ammonite feletzkytes dorfi, allowing chronostratigraphic control (Jagt \& Kennedy, 1994). In fact, the chronostratigraphic control was established in North America and the time-equivalence in Europe remains to be demonstrated. However, also belemnites (Keutgen, 1996) and ammonites (Jagt \& Felder, 2003) show that the Lower/Upper Maastrichtian boundary indeed should be placed approximately at the boundary between the Vijlen/Lixhe members; maybe at the Zonneberg Horizon just below (between the Vijlen units 5 and 6 ) as it represents a hiatus and a level across which there is a change in bioclast content. However, benthic foraminifera suggest a Lower/Upper Maastrichtian boundary slightly above the Zonneberg Horizon. In fact, the exact position is not yet known.

In the Knokke well, the youngest chalk is also of earliest Early Maastrichtian age and separated by a hiatus from the underlying Campanian chalk (Bal \& Verbeek, 1990). For this reason, the top of the chalk in the Knokke well ranges into the Vijlen Chalk sequence (Fig. 2). 


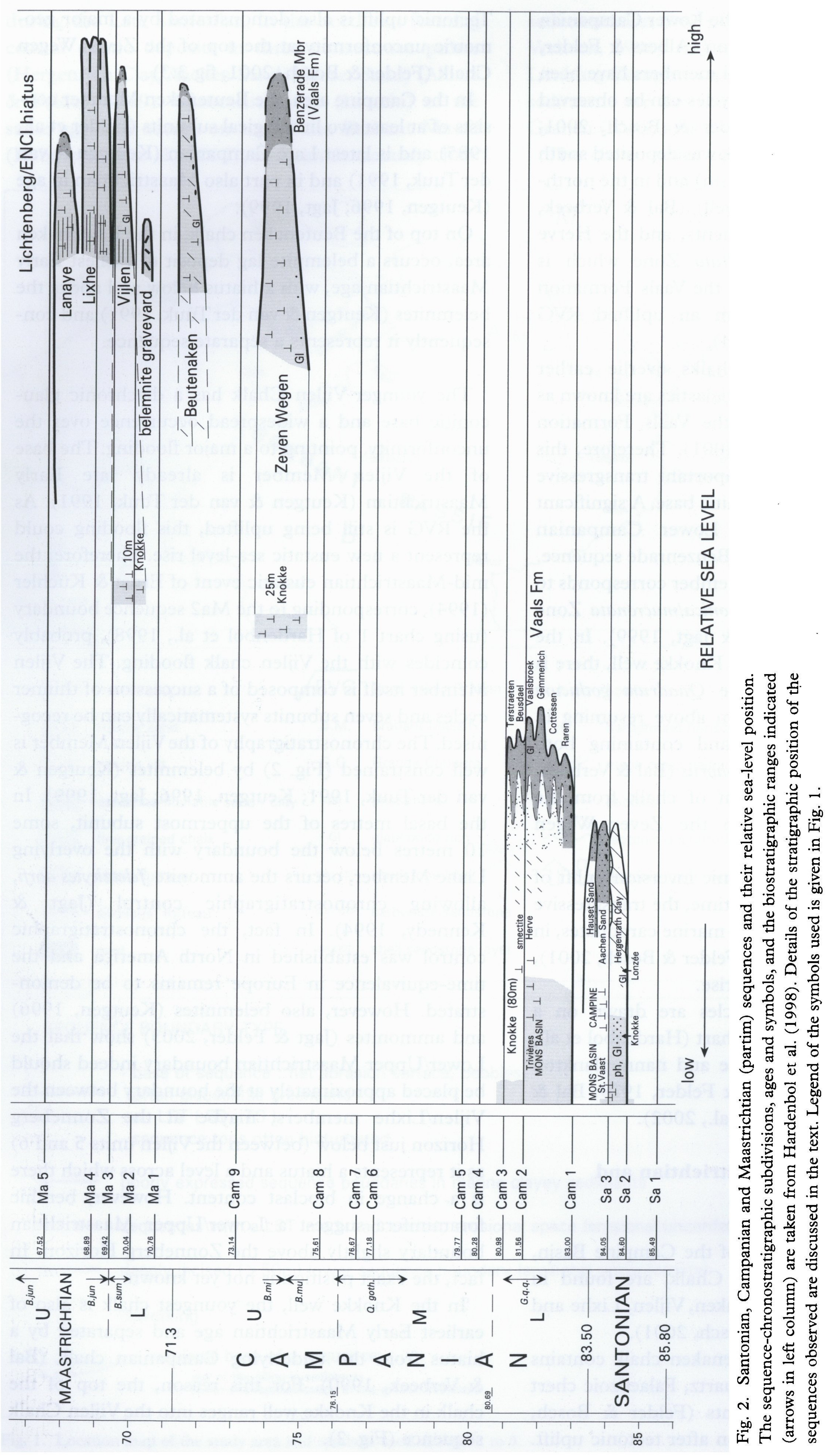


Above the Vijlen chalk occur the Lixhe and Lanaye members (Fig. 2), which are deeper and shallower facies, respectively, in comparison to the Vijlen chalk (Schiøler et al., 1997). The Lanaye Member is considered as a separate stratigraphic sequence because of the marked palynofacies change with respect to the Lixhe Member (Schiøler et al., 1997). Glauconitic sands which occur laterally of the Lanaye chalk facies (Fig. 2) represent the top of the Vaals Formation sensu Felder \& Bosch (2001).

Using flint characteristics, the Lixhe deposits are further subdivided into three lithostratigraphic units. The upper unit has a more widespread occurrence than the lower two units, pointing to still ongoing tectonic activity. In fact, the Lixhe 3 unit also covers the border of the Brabant Massif. Flints display a systematic layering which corresponds to precession cyclicity (Zijlstra, 1994). Duration of the 55 cycles of the Lixhe chalk can be estimated therefore at a minimum of 1.1 Ma. Based on the presence of feletzkytes dorfi (see discussion above), the age of the top of the Vijlen chalk corresponds to the top of the Hoploscaphites birkelundi Zone which is dated at $69.15 \mathrm{Ma}$ (Hardenbol et al., 1998, chart 5), leading to a maximum age for the top of the Lixhe chalk of about $68 \mathrm{Ma}$. Schiøler et al. (1997), however, estimated this level to be at $66.5 \mathrm{Ma}$, counting 55 precession cycles down from the Cretaceous/Paleogene boundary. In view of the ammonite calibration just below Lixhe, $68 \mathrm{Ma}$ is used in Fig. 2 (see below).

During the overlying Lanaye chalk sedimentation, inversion tectonics in the RVG was active (Schiøler et al., 1997; Felder \& Bosch, 2001). The 20 precession cycles in the Lanaye chalk suggest a maximum age estimate at the top of this unit of $67.6 \mathrm{Ma}$. Capping the Lanaye chalk is the Lichtenberg Horizon which separates the underlying fine chalks (Gulpen Formation) from overlying porous chalk arenites (tuffeau) of the Maastricht Formation.

Based on bioclast investigations, slightly different sequence boundaries in the Vijlen, Lixhe and Lanaye chalk succession could be chosen. As stated above, a lower sequence could start at the Zonneberg Horizon and include the Vijlen 6, Lixhe 1, Lixhe 2 and part of Lixhe 3, corresponding to bioclast ecozone IVa. An overlying sequence might include the top of Lixhe 3, Lanaye and continue up to the ENCI Horizon in the Maastricht area, which is located slightly above the base of the Maastricht Formation. Field investigation (P.J.F.) of the flint cycles in these two sequences points to a duration of about 1,2 to $1,3 \mathrm{Ma}$, the two cycles being of about equal duration. Using again the Lower/
Upper Maastrichtian boundary age as a geochronological reference level, the Lichtenberg-ENCI hiatus can be roughly dated at $68 \mathrm{Ma}$.

It can be concluded that, although slight differences in interpretation do exist, all available data point to two sequences of about equal duration in the chalks of Lixhe and Lanaye (including some chalk layers above and below) and to an important time hiatus at the levels of the Lichtenberg/ENCI horizons.

The arenite lithology and the palynomorphs (Schiøler et al., 1997) of the Maastricht Formation point to a shallow facies that was installed over the whole area after the last inversion. Only 35 precession cycles are reported from the Maastricht Formation between the Lichtenberg horizon and the K/P boundary (Zijlstra, 1994, cited in Schiøler et al., 1997), suggesting $0.7 \mathrm{Ma}$ for this interval and an age of about 65.7 Ma for the end of the Lichtenberg Horizon hiatus. Independent field investigations of the cycles (P.J.F.) lead to an age estimate of about $1 \mathrm{Ma}$ for the Maastricht Formation.

Both results are in obvious contrast with the earlier age estimate of the Lichtenberg Horizon of $68 \mathrm{Ma}$ based on the presence of feletzkytes dorfi and point to an important hiatus (see also Robaszynski et al., 1985, fig. 9). As the Vijlen, Lixhe and Lanaye chalks belong to a similar biozone (Robaszynski et al., 1985, pp. 14, 22) the hiatus occurs either mainly at the Lichtenberg level or within the arenitic chalks above that horizon.

Belemnella kazimiroviensis in the youngest member of the Maastricht Formation (Meerssen Chalk) cannot be used for chronostratigraphic control because of its diachronic appearance (Christensen, 1997). Precession cycle counting (Schiøler et al., 1997) and a preliminary $\mathrm{Sr}$ isotope interpretation (Vonhof \& Smit, 1996, p. 279) suggest a very short duration for the Maastricht Formation (Fig. 3). Palaeontologically, however, the Lichtenberg Horizon does not seem to represent an important change. Therefore, it is possible that not the Lichtenberg but a younger horizon (e.g., ENCI Horizon) represents most of the hiatus, but missing cycles, particularly in the very shallow Maastricht Formation, or the presence of other than precession cycles, also could explain some of the missing time interval.

Detailed palynofacies analysis (Schiøler et al., 1997), indicates that amongst the seven to eight regionally significant omission surfaces and/or hardgrounds in the Maastricht Formation, the Kanne (accumulation of echinoid debris) and Romontbos horizons (Fig. 3) can be interpreted as sequence boundaries subdividing the Maastricht Formation into three sequences. 
In the sequence interpretation shown in Fig. 3, somewhat more time is allowed than the minimal duration of $0.7 \mathrm{Ma}$ discussed earlier, in order to allow for probable hiatuses in the Maastricht Formation.

The K/P boundary is represented by local impactand storm-related sediments preserved between the Berg and Terblijt hardground (B\&T horizon in Fig. 3) and the Vroenhoven Horizon (Brinkhuis \& Smit, 1996). Above the Vroenhoven Horizon occurs a thin transgressive glauconitic chalk of earliest Danian age (Vandenberghe et al., 1998). To the north of the Brabant Massif, the Houthem Formation is the oldest Danian chalk deposit, while to the south, the oldest Danian units are represented by the Ciply chalk and Mons limestone. The latter are reported to belong to the NP3-NP4 biozone. As NP2 has also been reported for the Geulhem chalk (Houthem Formation) in Herngreen et al. (1998) and as in some sections this chalk unit clearly consists of two different lithological parts (see e.g. Ankerpoort-Curfs quarry section in Jagt (1999, Fig. 50)), two sequences are interpreted in the Houthem chalk (Fig.3). A hiatus occurs on top of the upper widely distributed chalk sequence, also marking the start of siliciclastic sediment input. In the Campine Basin, this hiatus is expressed as a marked seismic horizon (base clastic Tertiary reflection of Demyttenaere, 1989). A general tectonic uplift could have been responsible for this hiatus as it coincides with a major pulse in the magma emplacement leading to the generation of the North Atlantic Ocean opening (Andersen et al., 2002, Fig. 6).

\section{Selandian and Thanetian sequences and the transition to the Ypresian (Fig. 3)}

The oldest Cenozoic siliciclastic sediments, north and south of the Brabant Massif, have continental facies (Hainin and Opglabbeek formations). In contrast to Vandenberghe et al. (1998), the Maasmechelen calcarenite facies is here included in the continental Opglabbeek Formation. The continental deposits have an erosive base. Taking into account the current Danian/Selandian boundary definition (Berggren et al., 1995), these continental deposits may already belong to the Selandian (Steurbaut, 1998; Vandenberghe et al., 1998; Laga et al., 2002, p.138).

The Heers Formation consists of a transgressive glauconitic unit (Orp sand) overlain by the shallowwater cyclic Gelinden marls. No time-equivalent deposits occur south of the Brabant Massif. In situ nannoplankton in the formation ranges from NP4-5 to NP6, but almost $95 \%$ of the marl consists of reworked
Cretaceous chalk. A similar situation occurs in the Danish Kerteminde Marl of the same (Selandian) age pointing to widespread uplift in the North Sea area. Also the late Danian hiatus (Fig. 3) is found between the Danian limestones and the Kerteminde marl in Denmark (Michelsen et al., 1998). The HaininOpglabbeek continental deposits could be lowstand deposits of the Heers sequence although their geographic distribution with respect to the Heers Formation makes it more probable that they represent an individual sequence interrupted by tectonic uplift.

The marine part of the Landen Group (Maaseik to Bois Gilles units, Fig. 3) consists of lithological units with good nannoplankton data. Detailed geophysical log examination systematically shows two finingcoarsening cycles representing two sequences (Fig. 4). The lower sequence starts with the Maaseik marl (NP6) and mainly consists of the Waterschei clay unit (NP 7 to base NP8); the upper sequence consists of a silty-tuffaceous unit (Halen, Lincent, Angres, Cherq, St. Omer) and an overlying sandy unit (Grandglise sands), both deposited in NP8 chronozone (Steurbaut, 1998). All these deposits have time-equivalents on both sides of the Brabant Massif (including the Bertaimont Formation).

The thin Bois Gilles marine sand unit (early NP9 chronozone) is interpreted as a separate sequence (Vandenberghe et al., 1998), which is found south of the Brabant Massif only. Similar aged sands are known in northern France as the Criel sands (Dupuis \& Steurbaut, 1987). This geographical distribution suggests that the Brabant Massif became uplifted during the early NP9 chron.

The erosion accompanying this uplift is very well expressed at the base of the continental deposits of the Landen Group (Fig. 3) (Demyttenaere, 1989; De Batist \& Versteeg, 1999). The infill is partly fluviatile and partly brackish with 'Sparnacian'-type clay and fossils. These continental facies have been intensively studied in the past and also more recently as they straddle the newly defined Paleocene-Eocene boundary (Steurbaut et al., 1999). Generally occurring synsedimentary deformational structures in these continental deposits (Sintubin et al., 2001) are related to uplift reactivation of the Brabant Massif.

Both in Normandy (France) as well as in the Knokke well a thin cláy unit (Craquelinnes-Zoute silt in Figs. 3 and 4, or Knokke X-unit of King (1990)) overlies the continental Landen Group deposits. This unit contains volcanic glass shards (King, 1990). The sharp contact with the underlying sand points to a rapid transgression. However, renewed tectonic uplift 
Above the Vijlen chalk occur the Lixhe and Lanaye members (Fig. 2), which are deeper and shallower facies, respectively, in comparison to the Vijlen chalk (Schiøler et al., 1997). The Lanaye Member is considered as a separate stratigraphic sequence because of the marked palynofacies change with respect to the Lixhe Member (Schiøler et al., 1997). Glauconitic sands which occur laterally of the Lanaye chalk facies (Fig. 2) represent the top of the Vaals Formation sensu Felder \& Bosch (2001).

Using flint characteristics, the Lixhe deposits are further subdivided into three lithostratigraphic units. The upper unit has a more widespread occurrence than the lower two units, pointing to still ongoing tectonic activity. In fact, the Lixhe 3 unit also covers the border of the Brabant Massif. Flints display a systematic layering which corresponds to precession cyclicity (Zijlstra, 1994). Duration of the 55 cycles of the Lixhe chalk can be estimated therefore at a minimum of 1.1 Ma. Based on the presence of feletzkytes dorfi (see discussion above), the age of the top of the Vijlen chalk corresponds to the top of the Hoploscaphites birkelundi Zone which is dated at $69.15 \mathrm{Ma}$ (Hardenbol et al., 1998, chart 5), leading to a maximum age for the top of the Lixhe chalk of about $68 \mathrm{Ma}$. Schiøler et al. (1997), however, estimated this level to be at $66.5 \mathrm{Ma}$, counting 55 precession cycles down from the Creta- 
In the sequence interpretation shown in Fig. 3, somewhat more time is allowed than the minimal duration of $0.7 \mathrm{Ma}$ discussed earlier, in order to allow for probable hiatuses in the Maastricht Formation.

The K/P boundary is represented by local impactand storm-related sediments preserved between the Berg and Terblijt hardground (B\&T horizon in Fig. 3) and the Vroenhoven Horizon (Brinkhuis \& Smit, 1996). Above the Vroenhoven Horizon occurs a thin transgressive glauconitic chalk of earliest Danian age (Vandenberghe et al., 1998). To the north of the Brabant Massif, the Houthem Formation is the oldest Danian chalk deposit, while to the south, the oldest Danian units are represented by the Ciply chalk and Mons limestone. The latter are reported to belong to the NP3-NP4 biozone. As NP2 has also been reported for the Geulhem chalk (Houthem Formation) in Herngreen et al. (1998) and as in some sections this chalk unit clearly consists of two different lithological parts (see e.g. Ankerpoort-Curfs quarry section in Jagt (1999, Fig. 50)), two sequences are interpreted in the Houthem chalk (Fig.3). A hiatus occurs on top of the upper widely distributed chalk sequence, also marking the start of siliciclastic sediment input. In the Campine Basin, this hiatus is expressed as a marked seismic horizon (base clastic Tertiary reflection of Demyttenaere, 1989). A general tectonic uplift could have been responsible for this hiatus as it coincides with a major pulse in the magma emplacement leading to the generation of the North Atlantic Ocean opening (Andersen et al., 2002, Fig. 6).

\section{Selandian and Thanetian sequences and the transition to the Ypresian (Fig. 3)}

The oldest Cenozoic siliciclastic sediments, north and south of the Brabant Massif, have continental facies (Hainin and Opglabbeek formations). In contrast to Vandenberghe et al. (1998), the Maasmechelen calcarenite facies is here included in the continental Opglabbeek Formation. The continental deposits have an erosive base. Taking into account the current Danian/Selandian boundary definition (Berggren et al., 1995), these continental deposits may already belong to the Selandian (Steurbaut, 1998; Vandenberghe et al., 1998; Laga et al., 2002, p.138).

The Heers Formation consists of a transgressive glauconitic unit (Orp sand) overlain by the shallowwater cyclic Gelinden marls. No time-equivalent deposits occur south of the Brabant Massif. In situ nannoplankton in the formation ranges from NP4-5 to NP6, but almost $95 \%$ of the marl consists of reworked
Cretaceous chalk. A similar situation occurs in the Danish Kerteminde Marl of the same (Selandian) age pointing to widespread uplift in the North Sea area. Also the late Danian hiatus (Fig. 3) is found between the Danian limestones and the Kerteminde marl in Denmark (Michelsen et al., 1998). The HaininOpglabbeek continental deposits could be lowstand deposits of the Heers sequence although their geographic distribution with respect to the Heers Formation makes it more probable that they represent an individual sequence interrupted by tectonic uplift.

The marine part of the Landen Group (Maaseik to Bois Gilles units, Fig. 3) consists of lithological units with good nannoplankton data. Detailed geophysical log examination systematically shows two finingcoarsening cycles representing two sequences (Fig. 4). The lower sequence starts with the Maaseik marl (NP6) and mainly consists of the Waterschei clay unit (NP 7 to base NP8); the upper sequence consists of a silty-tuffaceous unit (Halen, Lincent, Angres, Cherq, St. Omer) and an overlying sandy unit (Grandglise sands), both deposited in NP8 chronozone (Steurbaut, 1998). All these deposits have time-equivalents on both sides of the Brabant Massif (including the Bertaimont Formation).

The thin Bois Gilles marine sand unit (early NP9 chronozone) is interpreted as a separate sequence (Vandenberghe et al., 1998), which is found south of the Brabant Massif only. Similar aged sands are known in northern France as the Criel sands (Dupuis \& Steurbaut, 1987). This geographical distribution suggests that the Brabant Massif became uplifted during the early NP9 chron.

The erosion accompanying this uplift is very well expressed at the base of the continental deposits of the Landen Group (Fig. 3) (Demyttenaere, 1989; De Batist \& Versteeg, 1999). The infill is partly fluviatile and partly brackish with 'Sparnacian'-type clay and fossils. These continental facies have been intensively studied in the past and also more recently as they straddle the newly defined Paleocene-Eocene boundary (Steurbaut et al., 1999). Generally occurring synsedimentary deformational structures in these continental deposits (Sintubin et al., 2001) are related to uplift reactivation of the Brabant Massif.

Both in Normandy (France) as well as in the Knokke well a thin clay unit (Craquelinnes-Zoute silt in Figs. 3 and 4, or Knokke X-unit of King (1990)) overlies the continental Landen Group deposits. This unit contains volcanic glass shards (King, 1990). The sharp contact with the underlying sand points to a rapid transgression. However, renewed tectonic uplift 


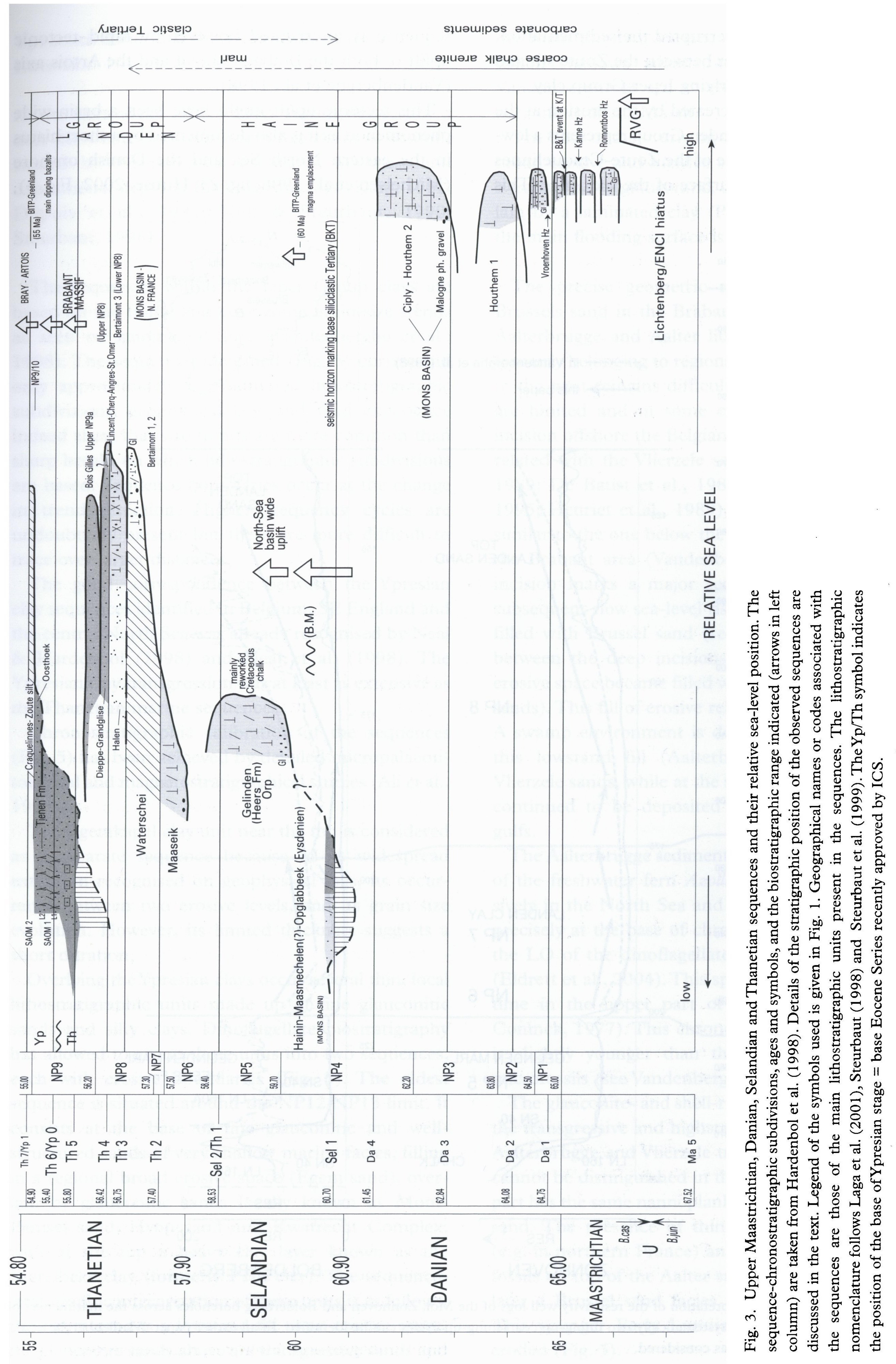


of the Brabant Massif interrupted the sedimentation, as shown by a pebble layer between the Zoute silt and the main mass of the overlying Ieper Group clay.

The infill of the space created by the erosion at the base of the continental Landen Group represents a lowstand deposit and the base of the Zoute-Craquelinnes silt is the transgressive surface of the sequence. This sequence is interrupted however by rapid tectonic uplift of both the Brabant Massif and the Artois axis (Vandenberghe et al., 1998).

This tectonic uplift might have been a basin-wide phenomenon as it is also documented by a short hiatus in the eastern North Sea and the Danish onshore (Michelsen et al., 1998, fig. 23; Huuse, 2002, Fig. 3).

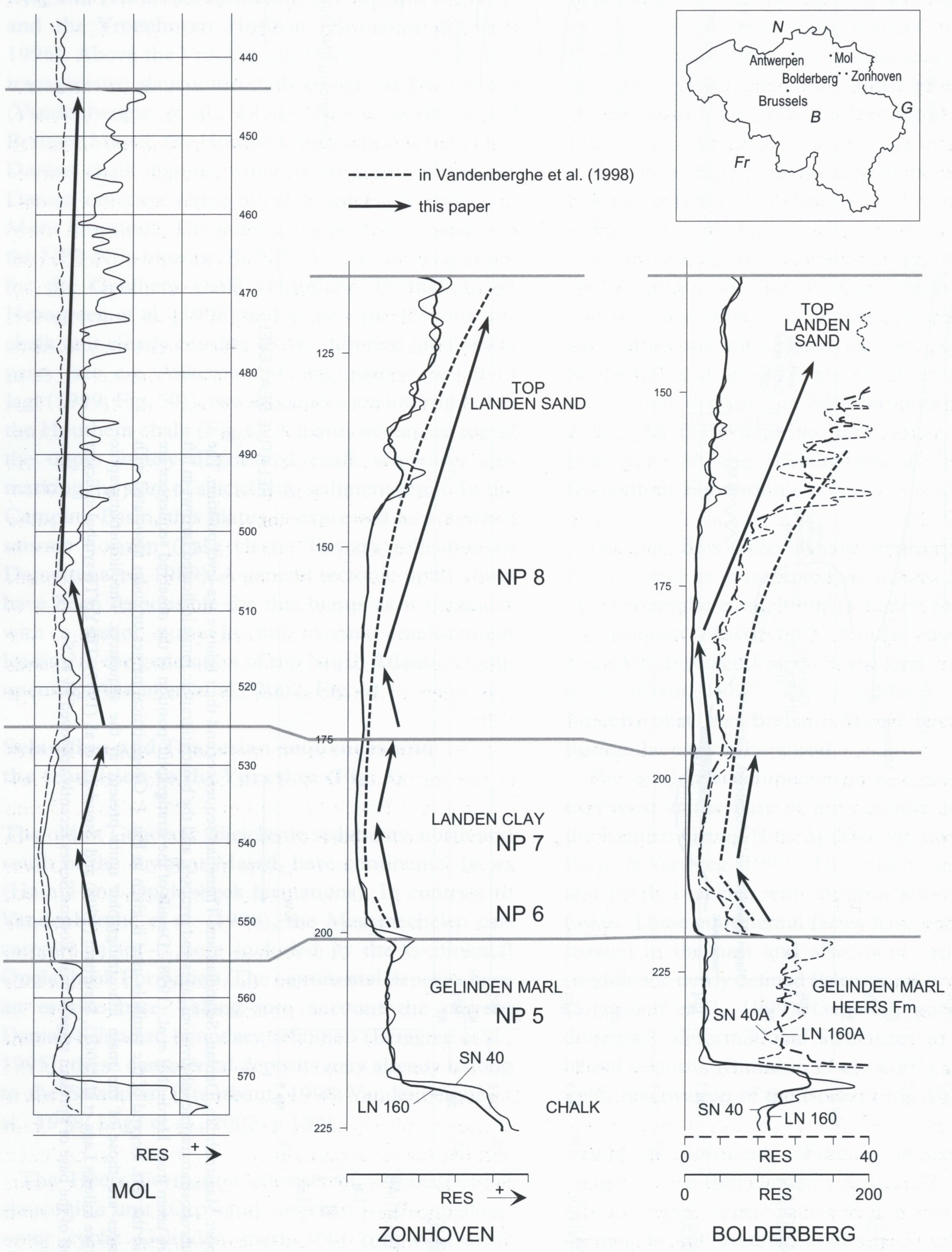

Fig. 4. The stratigraphic interpretation of the resistivity well logs of the Mol, Zonhoven and Bolderberg boreholes across the marine part of the Landen Group. Note that systematically two fining-up/coarsening-up cycles can be identified. In an earlier paper (Vandenberghe et al., 1998) only one longer cycle was considered. 
Ypresian time and the transition to the Lutetian

At the start of the NP10 chron, subsidence resumed over the whole southern North Sea Basin as demonstrated by the presence, extension, thickness and depositional depth of the Ypresian clays (King, 1981; Dupuis et al., 1984; Nolf \& Steurbaut, 1990; Steurbaut, 1998).

The sequences within the Ieper Group clays are based on the fining and coarsening grain-size trends as seen on gamma ray logs (Vandenberghe et al., 1998). The sequences identified (Fig. 5) correspond only approximately to traditional lithostratigraphic subdivisions; geophysical logs and field experience indeed show that size trends are more common than sharp breaks on which lithostratigraphic subdivisions are based. Sequence boundaries occur at the change in trend direction. Higher frequency cycles are undoubtedly present but these are more difficult to trace over larger distances.

The good correspondence between the Ypresian clay sequences identified in Belgium, SE England and the central North Sea was already recognised by Neal \& Hardenbol (1998) and Neal et al. (1998). The Ypresian clay transgression was at least as extensive as the Thanetian marine sequences.

Chronostratigraphic calibration of the sequences (Fig. 5) has been achieved by detailed micropalaeontological and magnetostratigraphical studies (Ali et al., 1993).

The Egemkapel clay unit near the top is considered as a separate sequence because of its widespread extension recognised on geophysical logs, its occurrence between two erosive levels, and its grain size evolution. However, its limited thickness suggests a short duration.

Overlying the Ypresian clays occur several thin, local lithostratigraphic units made up of fine glauconitic sands and silty clays. Dinoflagellate biostratigraphy has allowed to group these units into two sequences, each with erosive boundaries (Fig. 5). The oldest sequence is situated around the NP12/NP13 limit. It consists at the base of fine glauconitic and wellstructured sands of very shallow marine facies, filling in a regional broad erosive space (Egem sand), overlain by glauconitic sands locally known as MontPanisel sand, Hyon sand and Kwatrecht Complex, with at the top a heavy clay layer known as the Merelbeke clay (formerly $\mathrm{P} 1 \mathrm{~m}$ clay). The sequencestratigraphic interpretation of these units is as follows: the Egem sand is a lowstand fill of an erosive space, the glauconite sands above are transgressive sands and the main flooding surface is in the Merelbeke clay which shallows again towards its top (see also Vandenberghe et al., 1998). This sequence extends over the Brabant Massif.

The base of the overlying sequence is also a regional broad erosive and incisive surface over which occurs a transgressive glauconitic, shell-rich sandstone overlain by a laminated clay (Pittem clay) within which the main flooding surface is situated (Fig. 5).

The precise geometric relationship between the Brussels sand in the Brabant area and the Vlierzele, Aalterbrugge and Aalter lithostratigraphic units (all formerly belonging to regional 'Paniselien' stage) more to the west remains difficult as biostratigraphic data are limited and in some cases conflicting. A deep incision offshore the Belgian coast, geometrically correlated with the Vlierzele sands onshore (De Batist, 1989; De Batist et al., 1989; De Batist \& Henriet, 1995; Henriet et al., 1989), has been interpreted as similar to the one below the mass of Brussel sands in the Brabant area (Vandenberghe et al., 1998). This incision marks a major sequence boundary. Upon subsequent slow sea-level rise the incised valleys were filled with Brussel sand (see also Houthuys, 1990); between the deep incisions, shallower and broader erosive space became filled with tidal ridges (Vlierzele sands). This fill of erosive relief is a lowstand deposit. A swamp environment is documented in the top of this lowstand fill (Aalterbrugge unit) above the Vlierzele sands, while at the same time Brussels sands continued to be deposited in broad estuarine-type gulfs.

The Aalterbrugge sediments contain isolated records of the freshwater fern Azolla sp. which occurs massively in the North Sea and even the Atlantic Ocean precisely at the base of chron $\mathrm{C} 21 \mathrm{r}$, coinciding with the LO of the dinoflagellate cyst Eatonicysta ursulae (Eldrett et al., 2004). This species appears for the last time in the upper part of the Vlierzele sand (De Coninck, 1977). This chronostratigraphic calibration is slightly younger than that based on calcareous microfossils (see Vandenberghe et al., 1998) (Fig. 5).

The glauconite- and shell-rich Aalter sands represent the transgressive and highstand deposits covering the Aalterbrugge and Vlierzele units. These system tracts cannot be distinguished in the Brussel sand, which in part has the same nannoplankton biozone as the Aalter sand. The presence of thin Brussel sand remnants (e.g. in northern France) and reworked Brussel sand fossils on top of the Aalter sand suggests that slightly later a Brussel sand facies covered the whole area. This younger Early Lutetian sequence was largely eroded (Fig. 5). 
রu!

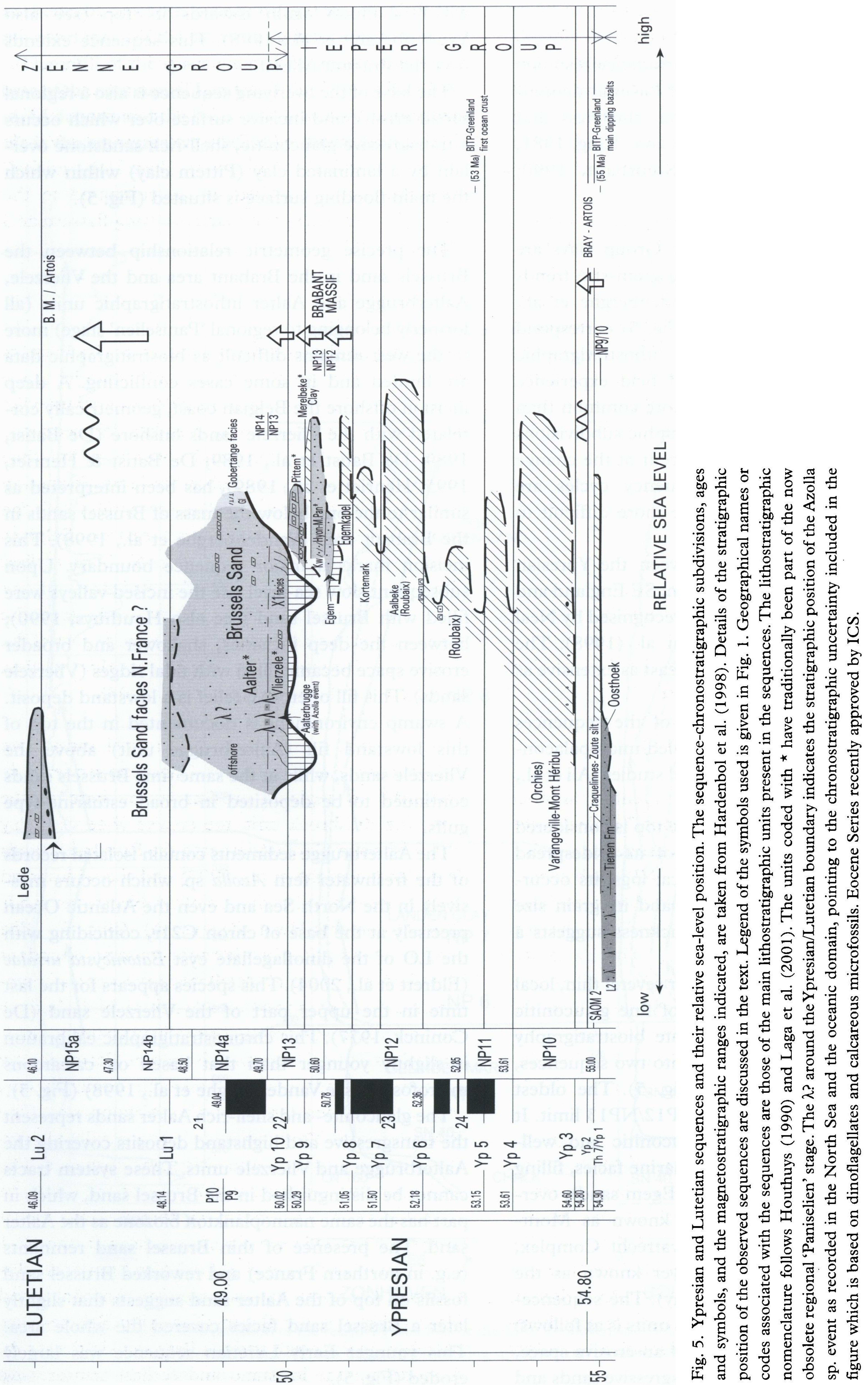


The markedly erosive bases of the Late Ypresian Early Lutetian sequences and the paleoseismites in the Egem and Brussels sands (Herman et al., 2001), are indications of active uplift of the Brabant and Artois blocks leading to the separation of the Paris Basin from the North Sea Basin.

\section{The Lutetian, Bartonian and Priabonian}

The continued uplift is shown by long hiatuses in the Middle and Upper Eocene (Figs. 5 and 6). A long period of sedimentation, emersion and reworking during the early biochron NP15a appears from detailed analyses of the basal gravel of the Lede sand (Herman et al., 2001; Smith et al., 2003). The Lede sands represent a Middle Lutetian sequence at the base of the biochron NP15b, probably the expression of the $\mathrm{Lu} 2$ sequence reported in the European basins (Hardenbol et al., 1998) (Fig. 6).

The Lede sands are eroded at the top. An important hiatus separates the Lede and the overlying Wemmel sands.

The fine Wemmel sands, rich in Nummulites and glauconite, represent a new transgression. Authigenic glauconite occurs also concentrated into a conspicuous black horizon (bande noire) at the base of overlying transgressive Asse/Ursel clay, which contains the main flooding surface. This WemmelAsse sequence is situated around the NP15/NP16 boundary (Vandenberghe et al., 1998).

Geophysical well logs further identify another Lutetian and also a Bartonian sequence (Vandenberghe et al., 1998). This second Lutetian sequence consists of glauconitic transgressive sands (NP 16 biozone) overlain by deeper-water Zomergem clay (containing the main flooding surface), and sands at the top (lower part of the Buisputten unit). The Bartonian sequence consists of a transgressive sand (upper part of the Buisputten unit) and a deeper-water Onderdijke clay eroded at the top, which contains Bartonian dinoflagellates. The overlying Bassevelde sand yields Priabonian microfossils (Vandenberghe et al., 2003) (Fig. 6).

Lutetian, Bartonian and Priabonian sequences do not extend into northeast Belgium. Biostratigraphy, well-log correlation and clay mineral data (Saeys et al., this volume) show the level of the eroded Bartonian Onderdijke clay top to correlate with the main unconformity below the Sint-Huibrechts-Hern Formation (Tongeren Group) in eastern Belgium. The tilting of the strata below the unconformity therefore occurred at the Bartonian-Priabonian boundary (Pyrenean phase).
A recent, detailed study of the Bassevelde sands has established three biostratigraphically well-constrained sequences (Vandenberghe et al., 2003) that can be consistently mapped in northern Belgium (Verheyen, 2003) (Fig. 6). The oldest (Bal) has a transgressive glauconitic base and formed within biozone NP18. The middle sequence $(\mathrm{Ba} 2)$ formed during the Middle Priabonian (NP19-20 biozone). Both $\mathrm{Ba} 1$ and $\mathrm{Ba} 2$ sequences have a limited extent compared to the underlying sequences and to the overlying Bassevelde 3 sequence.

\section{The Oligocene}

The youngest Bassevelde sand sequence ( $\mathrm{Ba} 3$ ) starts with a transgressive glauconitic sand while its top is characterized by an open marine clay (Watervliet clay). Biostratigraphical data correlate this sequence to the earliest Oligocene and show it to be time equivalent with the Sint-Huibrechts-Hern Formation (Grimmertingen and Neerrepen sands) of the Tongeren Group in central and eastern Belgium (Vandenberghe et al., 2003) (Fig. 6). This earliest Oligocene sequence covered the Ardennes to the south (De Coninck, 1996) and probably even the Lorraine area (France, Luxemburg) where part of the Pierre de Stonne could represent this earliest Oligocene sand (see Quesnel et al., 2003).

An outspoken low relative sea level must have followed this extensive earliest Oligocene sequence as evidenced by regional erosion at the base of the overlying Ruisbroek unit, the erosive Watervliet clay top, freshwater clays underneath the Ruisbroek sands (e.g. Vandenberghe et al., 2003) and the widespread occurrence of a soil at the top of the Neerrepen sands (Sint-Huibrechts-Hern Formation) (Fig. 6). The shallow marine Ruisbroek sand contains abundant reworked microfossils. At their top occurs a transgressive level of phosphate-cemented bioturbations and internal moulds of molluscs. Further south, timeequivalent coastal deposits (Borgloon Formation or continental deposits of the Tongeren Group) occur, topped by a transgressive black pebble horizon. The Ruisbroek and Borgloon units are considered lowstand deposits of a second Oligocene sequence. The important low sea level at the base of the sequence coincides with the significant temperature drop known in the earliest Oligocene and correlates to the Oi-1 glaciation of Zachos et al. (2001) (De Man et al., this volume). Overlying the transgressive phosphates and black pebbles is the Boom Clay (silty Belsele-Waas Member) in the north and the Berg sand in the south. A model for the lowstand and earliest transgressive 


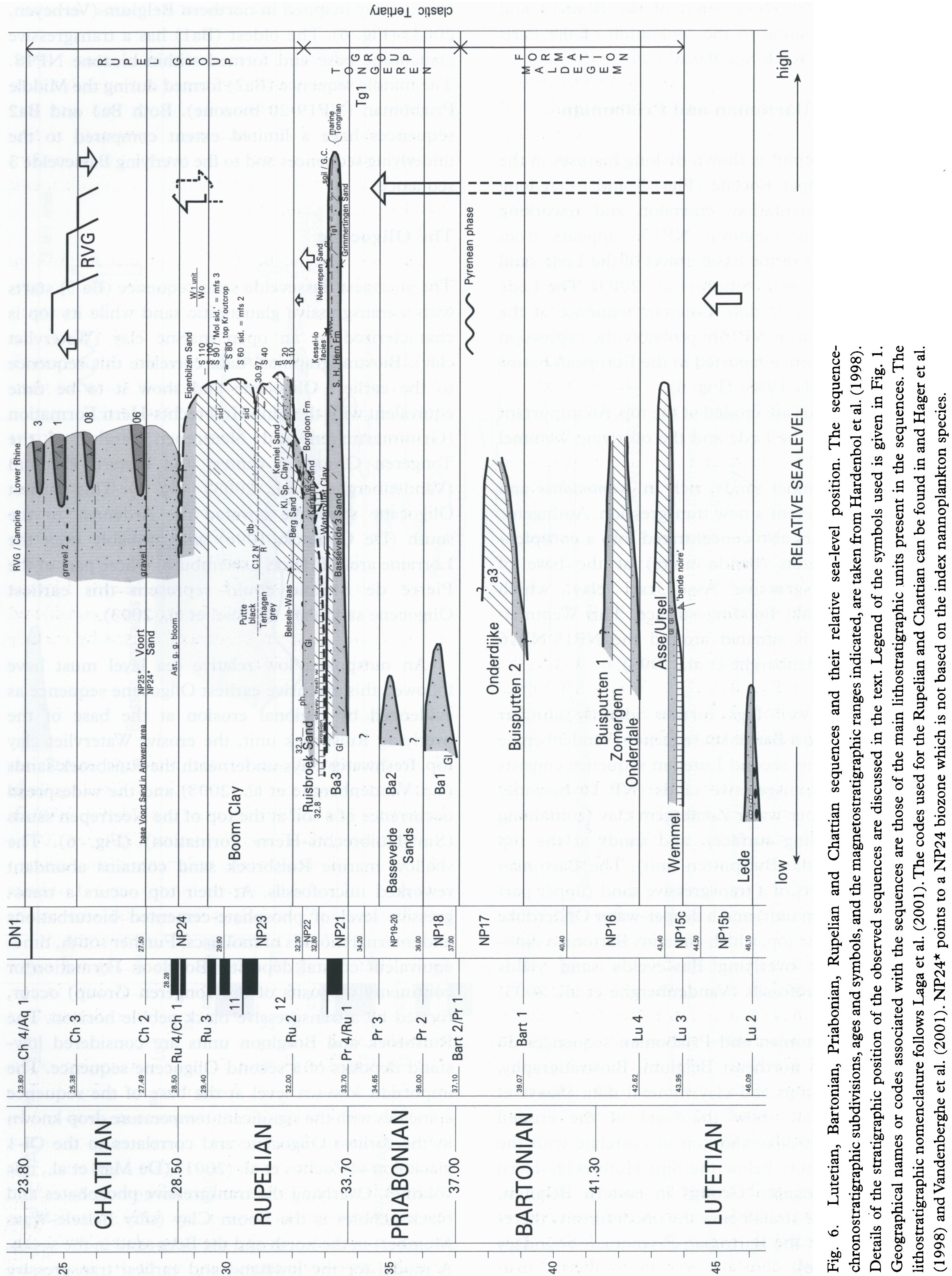


sedimentation of this sequence was discussed by Vandenberghe et al. (2002).

The Boom Clay (Rupelian unit stratotype) has a widespread occurrence in the North Sea Basin. The clay has an outspoken decimetre-scale layering interpreted as Milankovitch periodicity (Van Echelpoel \& Weedon, 1990). New magnetostratigraphic and dinoflagellate calibration horizons (Lagrou et al., this volume) and the cyclostratigraphic understanding of the more complete subsurface sections (Vandenberghe et al., 2001) necessitate a reinterpretation of the periodicities.

Based on grain-size, clay mineral and organic matter properties the Milankovitch layering has been related to climate-driven relative sea-level variations (Vandenberghe et al., 1997). Grouping of layers on the geophysical resistivity log of the Boom clay has been related to long eccentricity cycles $(400 \mathrm{ka})$ by Hardenbol et al. (2003). Such longer cycles are probably related to sediment-supply cycles and intermediate geochemical-mineralogical cycles as discussed by Laenen $(1997,1998)$ and Vandenberghe et al. (1997) (Fig. 6).

Lower frequency grain size evolutions, interpreted as third-order sequences, are superimposed on the Milankovitch induced layering (Vandenberghe et al., 1998). Two such sequences are identified in the outcrop area of the Boom clay. In the subsurface, an additional and younger sequence is suggested (Vandenberghe et al., 2001). The Boom clay in the subsurface always ends in a coarsening silty to fine sandy facies (Eigenbilzen unit) (Fig. 6).

Resistivity logs show that from the base of the Ruisbroek unit to the top of the Boom clay (see e.g. logs in Vandenberghe et al., 2001), the 3rd order sequences and the Milankovitch cycles are superimposed on a single long duration cycle. This longer cycle is expressed in the bed thicknesses and therefore probably reflects the ongoing Alpine compressive tectonics in southern Europe (see Vandenberghe et al. 1997). The tectonic influence might be an explanation for the discrepancy between the Rupelian oxygen isotopes and global sea-level curves as apparent from data in Abreu \& Haddad (1998, Figs. 7 and 8). The Kerniel sand wedge in the lower 3rd order sequence (Fig. 6) is also the result of a local tectonic pulse (Vandenberghe et al., 2001).

The sudden change from grey to black clays (Fig. 6) in the Boom Formation is due to better preservation conditions for organic matter (Laenen, 1998). This level is remarkably constant over the southern North
Sea Basin (Vandenberghe et al. 2001) and can biostratigraphically be correlated with the base of the Fish clays in the Mainz Basin (Grimm \& Steurbaut 2001). This must point to an important palaeogeographic change.

At the end of the Rupelian, important uplift occurred. This is shown by important end-Rupelian or earliest Chattian erosion in the outcrop area (see Mertens et al., 2003) and the deposition of fine sandier sediment towards the top of the Rupelian, especially in the later graben area in the northeast (Vandenberghe et al., 2001).

The end-Rupelian uplift of the area is followed at the beginning of the Chattian by the strong subsidence of the entire Lower Rhine area. The westernmost graben fault is located near Mol (Fig.1). Its stratigraphy and age is discussed in Van Simaeys et al. (2004). The main continuous mass of Chattian glauconitic sand occurs to the east of this fault.

Based on geophysical logs, mainly of the lower Rhine brown coal area, Hager et al. (1998, Figs. 4, 5) systematically identified four continental clay and lignite intercalations in the marine glauconitic sands in the area. Based on dinoflagellate data, the lower and upper lignitic clays can be correlated to gravelly horizons in the marine glauconitic facies. Lignitic clays and correlative gravelly horizons are considered as boundaries between sequences caused by eustacy (Hager et al., 1998) (Fig. 6).

\section{The Neogene}

Biostratigraphy of glauconitic Neogene sands has recently improved greatly by studies of dinoflagellates (Louwye \& Laga, 1998; Louwye et al., 1999, 2000, in press; Louwye, 2001) and Bolboforma (Spiegler, 2001).

Early and Middle Miocene sediments of the Antwerp (Edegem, Kiel, Antwerpen units) and Limburg (Houthalen, Genk and Opgrimbie units) area can be grouped into three sequences (Vandenberghe et al., 1998) (Fig. 7). The relatively thin sediments range from Early Burdigalian to Earliest Serravallian in age. Aquitanian and the main part of the Serravallian intervals are absent.

The Diest, Dessel and Deurne glauconitic sands are of Tortonian to early Messinian age (Fig. 7). The age of the very deep erosion underlying these sands, known from drilling, mapping and seismics, is not exactly known. In northern Belgium, seismics (De Batist \& Versteeg, 1999) and dinoflagellate studies in several boreholes (Louwye et al., 1999), confirm an early local observation by Demyttenaere (1989) that here the large-scale cross bedding of the Diest sand 


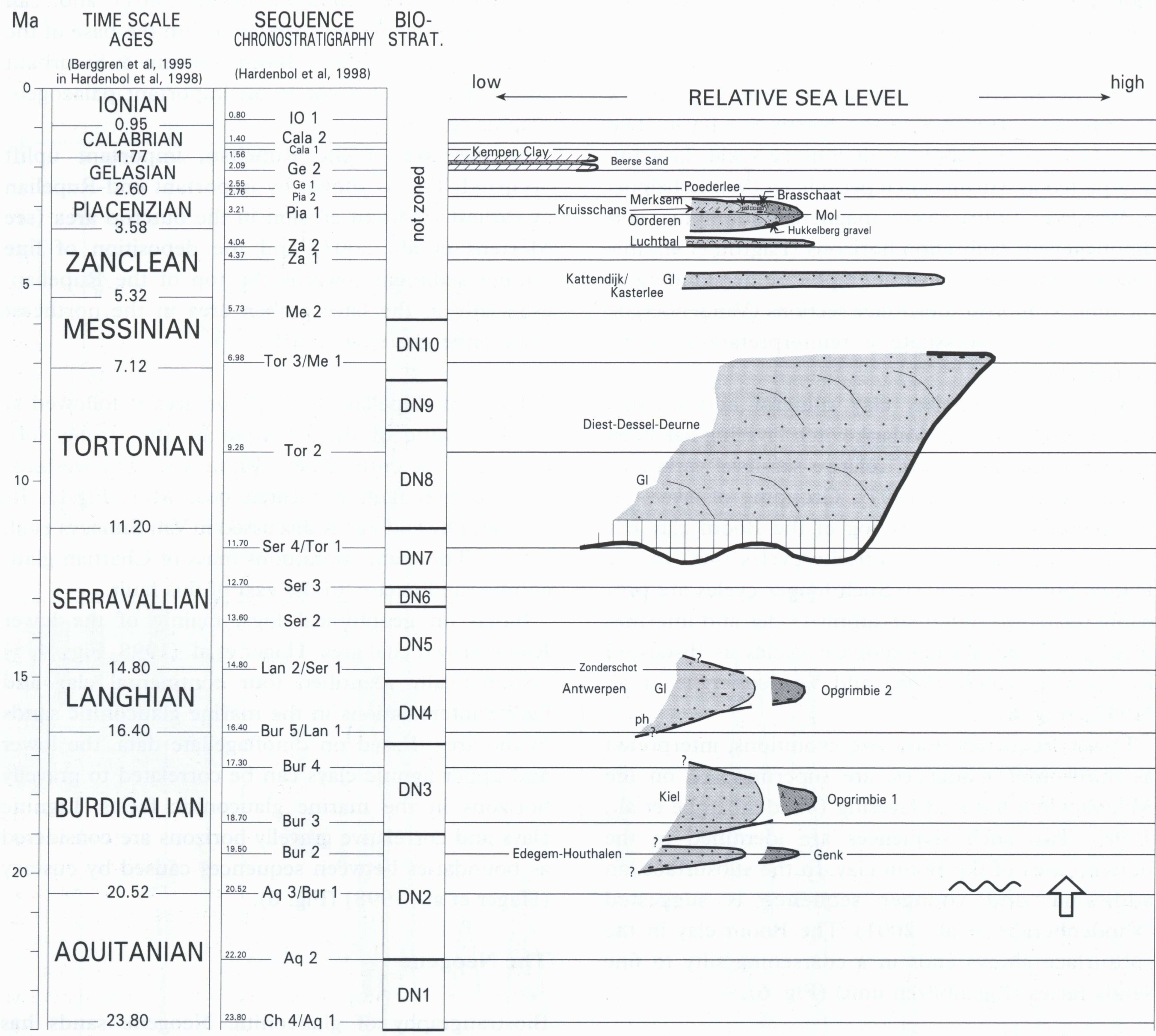

Fig. 7. Neogene and Pleistocene sequences and their relative sea-level position. The sequence-chronostratigraphic subdivisions, ages and symbols, and the magnetostratigraphic ranges indicated, are taken from Hardenbol et al. (1998). The dinoflagellate zonation (DN) was used by Louwye et al. (1999). Details of the stratigraphic position of the observed sequences are discussed in the text. Legend of the symbols used is given in Fig. 1. Geographical names or codes associated with the sequences are those of the main lithostratigraphic units present in the sequences. The lithostratigraphic nomenclature follows Laga et al. (2001).

progrades to the northwest whilst in the southern classic Hageland area sediment transport occurred to the northeast. The strong erosion at the base, the marked prograding fill and the increased sediment supply point to important tectonic uplift.

Pliocene deposits are preserved only in the very north of Belgium reflecting continued global sea-level lowering. Improved chronostratigraphic position of the different sequences compared to Vandenberghe et al. (1998), is based on dinoflagellates. The ordering into two sequences of the different facies of the Lillo, Poederlee, Brasschaat, Merksplas and Mol formations was discussed by Vandenberghe et al. (2001).
Marine sedimentation in the area stops at the beginning of the Gelasian due to the strong climate deterioration in the area bringing periglacial conditions over the area. Younger indications of marginal marine tidal flat or estuarine sediments are known only in the Tiglian, Holsteinian, Eemian and Holocene interglacials.

\section{Conclusions}

The Late Cretaceous to Pliocene stratigraphic succession in the Campine basin and adjacent areas is presented in a sequence-chronostratigraphic framework. 
The duration of the different sequences is quite variable and different periods may reflect different controls. Combining the analysis with regional geological history data, tectonic and eustacy controls are distinguished. Tectonics generally acted more slowly than eustatic changes. In these shallow, near-coastal facies generally only transgressive and highstand system tracts are well expressed. Lowstand deposits only occur when erosive bases rather than flat abrasion surfaces underlie a sequence. Marked erosive bases can mostly be related to active uplift of the area.

\section{Acknowledgements}

The research has benefited from the financial support of the F.W.O. (grant G.0093.01N/E8).

\section{References}

Abreu, V.S. \& Haddad, G.A., 1998. Glacioeustacy: the mechanism linking isotope event and sequence stratigraphy. In: de Graciansky, P.-C., Hardenbol, J., Jacquin, T., Vail, P.R. (eds): Mesozoic and Cenozoic Sequence Stratigraphy of European Basins. Society for Sedimentary Geology (SEPM), Special Publication 60: 245-259.

Albers, H.-J. \& Felder, W.M., 1979. Litho-, Biostratigraphie und Palökologie der Oberkreide und des Alttertiärs (PräobersantonDan/Paläozän) von Aachen-Südlimburg (Niederlande, Deutschland, Belgien). In: Wiedmann, J. (ed): Aspekte der Kreide Europas. International Union of Geological Sciences, A (6): 47-84.

Ali, J.R., King, C. \& Hailwood, E.A., 1993. Magnetostratigraphic calibration of early Eocene depositional sequences in the southern North Sea Basin. In: Hailwood, E.A. \& Kidd, R.B. (eds): High Resolution Stratigraphy. Geological Society London, Special Publication 70: 99-125.

Andersen, M.S., Sørensen, A.B., Boldreel, L.O. \& Nielsen, T., 2002. Cenozoic evolution of the Faroe Platform: comparing denudation and deposition. In: Doré, A.G., Cartwright, J.A., Stoker, M.S., Turner, J.P. \& White, N. (eds): Exhumation of the North Atlantic Margin: Timing, Mechanisms and Implications for Petroleum Exploration. Geological Society London, Special Publication 196: 291-311.

Bal, S.G. \& Verbeek, J.W., 1990. Upper Cretaceous nannoplankton in the Knokke well. In: Laga, P. \& Vandenberghe, N. (eds): The Knokke well (1lE/138) with a description of the Den Haan $(22 \mathrm{~W} / 276)$ and Oostduinkerke (35/142) wells. Toelichtende Verhandelingen voor de Geologische en Mijnkaarten van België (Brussel) 29: 63-66.

Berggren, W. A., Kent, D.V., Swisher, C.C. III \& Aubry, M.-P., 1995. A revised Cenozoic geochronology and chronostratigrapy. In: Berggren, W.A., Kent, D.V., Aubry, M.-P. \& Hardenbol, J. (eds): Geochronology, time scales, and global stratigraphic correlation. Society for Sedimentary Geology (SEPM), Special Publication 54: 129-212.

Brinkhuis, H. \& Smit, J. (eds) 1996. The Geulhemmerberg Cretaceous/Tertiary boundary section (Maastrichtian type area, SE Netherlands). Geologie en Mijnbouw 75: 101-293.

Christensen, W.K., 1997. Palaeobiogeography and migration in the Late Cretaceous belemnite family Belemnitellidae. Acta palaeontologica polonica 42: 457-495.
De Batist M., 1989. Seismostratigrafie en struktuur van het Paleogeen in de Zuidelijke Noordzee. Doctoraatsthesis, R.U. Gent: 107 pp., 136 figs.

De Batist, M. \& Henriet, J.P., 1995. Seismic sequence stratigraphy of the Paleogene offshore of Belgium, southern North Sea. Journal of the Geological Society of London 152: 27-40.

De Batist, M. \& Versteeg, W.H., 1999. Seismic stratigraphy of the Mesozoic and Cenozoic in northern Belgium: main results of a high-resolution reflection seismic survey along rivers and canals. Geologie en Mijnbouw 77: 17-37.

De Batist M., De Bruyne, H., Henriet, J.P. \& Mostaert F., 1989. Stratigraphic analysis of the Ypresian of the Belgian coast. In: Henriet, J.P., De Moor, G. \& De Batist, M. (eds): The Quaternary and Tertiary Geology of the Southern Bight, North Sea. Belgian Geological Survey, Ministry of Economic Affairs (Brussels): 75-88.

De Coninck, J., 1977. Een afzettingshiaat tussen het Ieperiaan en het Lutetiaan te Melle-Heusden. Natuurwetenschappelijk Tijdschrift (Gent) 57 (1975): 224-229.

De Coninck, J., 1996. Indicateurs biostratigraphiques du phytoplancton à paroi organique des sables marins du Tertiaire à ORET (Entre-Sambre-et-Meuse). Bulletin de la Société belge de Géologie 104: 151-161.

De Man, E., Ivany, L. \& Vandenberghe, N., (this volume). Stable oxygen isotope record of the Eocene-Oligocene transition in $\mathrm{NE}$ Belgium. Netherlands Journal of Geosciences.

Demyttenaere, R., 1989. The Post-Paleozoic Geological History of North-Eastern Belgium. Mededelingen van de Koninklijke Academie voor Wetenschappen, Letteren en Schone Kunsten in België, Klasse Wetenschappen 51(4): 51-81.

Dupuis, C. \& Steurbaut, E., 1987. Altérites, sables marins (NP8, NP9) et fluviatiles, silicification et stromatolithes dans le Paléocène supérieur entre Criel et le Cap d'Ailly (Haute-Normandie). Annales de la Société Géologique du Nord (Lille) 105: 233-242.

Dupuis, C., De Coninck, J. \& Roche E., 1984. Remise en cause du rôle paléogéographique du horst de l'Artois à I'Yprésien inférieur. Mise en évidence de I'intervention du Môle Bray-Artois. Comptes Rendus de l'Académie des Sciences (Paris) 298 II (2): 53-56.

Eldrett, J., Harding, I.C., Firth, J.V. \& Roberts, A.P., 2004. Magnetostratigraphic calibration of Eocene-Oligocene dinoflagellate cyst biostratigraphy from the Norwegian-Greenland Sea. Marine Geology 204, 91-127.

Ernst, G. \& Küchler, T., 1994. Tecto-eustasy: control of sea level movements by means of isochronous tecto-events, exemplified by Upper Cretaceous basin analyses of $\mathrm{N}$. Germany and $\mathrm{N}$. Spain. In: Sequence stratigraphy of European Basins (Dijon, May 18-20, 1992). Abstract Volume (Centre National de Recherche Scientifique- Institut Français de Pétrole): 128-129.

Felder, P.J., Bless, M.J.M., Demyttenaere, R., Dusar, M., Meessen, J.P.M.Th. \& Robaszynski, F., 1985. Upper Cretaceous to Early Tertiary deposits (Santonian-Paleocene) in northeastern Belgium and south Limburg (The Netherlands) with reference to the Campanian-Maastrichtian. Geologische Dienst van België, Professional Paper 214: $151 \mathrm{pp}$.

Felder, W.M. \& Bosch P.W., 2001. Geologie van Nederland, deel 5 Krijt van Zuid-Limburg, Nederlands Instituut voor Toegepaste Geowetenschappen TNO (Delft/Utrecht): $192 \mathrm{pp}$.

Grimm, K.I. \& Steurbaut, E., 2001. Foraminiferal Biofacies Analysis of the Boom Clay Formation in the Rupel area (Oligocene, Belgium) and Correlation with the Mainz Basin (Germany). Aardkundige Mededelingen (Leuven) 11: 9-20.

Gullentops, F., 1963. Etude de divers faciès quaternaires et tertiaires dans le Nord et l'Est de la Belgique. $6^{\mathrm{e}}$ Congrès International de 
Hager, H., Vandenberghe, N., van den Bosch, M., Abraham, M., von der Hocht, F., Rescher, K., Laga, P., Nickel, E., Verstraelen, A., Leroi, S. \& van Leeuwen, R.J.W., 1998. The geometry of the Rupelian and Chattian depositional bodies in the Lower-Rhine district and its border area: implications for Oligocene lithostratigraphy. Bulletin of the Geological Society of Denmark 45: 53-62.

Hardenbol, J., Thierry, J., Farley, M.B., Jacquin, T., de Graciansky, P.-C. \& Vail, P.R., 1998. Mesozoic and Cenozoic sequence chronostratigraphic framework of European Basins. In: de Graciansky, P.-C., Hardenbol, J., Jacquin, T. \& Vail, P.R. (eds): Mesozoic and Cenozoic Sequence Stratigraphy of European Basins. Society for Sedimentary Geology (SEPM), Special Publication 60: 3-14, appendix 763-782 + 8 charts.

Hardenbol, J., Vandenberghe, N., Van Simaeys, S. \& De Man, E., 2003. Sequence Stratigraphy of the Boom Clay in Belgium. Addendum to Field trip guide to the Rupelian Stratotype. Symposium on the Paleogene (Leuven, August 25-30, 2003). International Subcommission on Paleogene Stratigraphy: 5 pp.

Henriet, J.P., De Batist, M., De Bruyne, H., Heldens, P., Huylebroeck, J.P., Mostaert, F., Sevens, E., Auffret, J.P. \& D'Olier B., 1989. Preliminary seismic-stratigraphic maps and type sections of the Paleogene deposits in the Southem Bight of the North Sea. In: Henriet, J.P., De Moor, G. \& De Batist, M. (eds): The Quaternary and Tertiary Geology of the Southern Bight, North Sea. Belgian Geological Survey, Ministry Economic Affairs (Brussels): 29-44.

Herman, J., Steurbaut, E. \& Vandenberghe, N., 2001. The boundary between the Middle Eocene Brussel Sand and the Lede Sand formations in the Zaventem-Nederokkerzeel area (northeast of Brussels, Belgium). Geologica Belgica (Brussel) 3 (2000): 231-255.

Herngreen, G.F.W., Schuurman, H.A.H.M., Verbeek, J.W., Brinkhuis, H., Burnett, J.A., Felder, W.M. \& Kedves, M., 1998. Biostratigraphy of Cretaceous/Tertiary boundary strata in the Curfs quarry, The Netherlands. Mededelingen van het Nederlands Instituut voor Toegepaste Geowetenschappen TNO 61: 1-58.

Houthuys, R., 1990. Vergelijkende studie van de afzettingsstruktuur van getijdenzanden uit het Eoceen en van de huidige Vlaamse banken. Aardkundige Mededelingen (Leuven University Press) 5: $1-137$.

Huuse, M., 2002. Cenozoic uplift and denudation of southern Norway: insights from the North Sea Basin. In: Doré, A.G., Cartwright, J.A., Stoker, M.S., Turner, J.P. \& White, N. (eds): Exhumation of the North Atlantic Margin:Timing, Mechanisms and Implications for Petroleum Exploration. Geological Society London, Special Publication 196: 209-233.

Jagt, J.W.M., 1999. Late Cretaceous-Early Paleogene echinoderms and the $\mathrm{K} / \mathrm{T}$ boundary in the southeast Netherlands and northeast Belgium- Part 1: Introduction and stratigraphy. Scripta Geologica 116: 1-57.

Jagt, J.W.M. \& Kennedy, W.J., 1994. Jeletzkytes dorfi Landman \& Waage 1993, a North American ammonoid marker from the lower Upper Maastrichtian of Belgium, and the numerical age of the Lower/Upper Maastrichtian boundary. Neues Jahrbuch für Geologie und Paläontologie Monatshefte 1994(4): 239-245.

Jagt, J.W.M. \& Felder, W.M., 2003. The stratigraphic range of the index ammonite Pachydiscus neubergicus (von Hauer, 1858) in the type area of the Maastrichtian Stage. In: Jagt, J.W.M., Schulp, A.S. \& De Graaf, D.T. (eds). The 150th anniversary of the Maastrichtian Stage: a celebratory conference. Netherlands Journal of Geosciences 82: 261-268.

Jagt, J.W.M., Kennedy, W.J., Burnett, J.A., Christensen, W.K. \& Dhondt, A.V. 1995. Santonian macrofauna and nannofossils from northeast Belgium. Bulletin de l'Institut royal des Sciences naturelles de Belgique, Sciences de la Terre, 65: 127-137.
Keutgen, N., 1996. Biostratigraphie, Paläoökologie und Invertebratenfauna des Untermaastricht von Aachen (Westdeutschland) und angrenzenden Gebieten (Südostniederlande, Nordostbelgien). Shaker Verlag (Aachen): iii + 213 pp.

Keutgen, N. \& Jagt, J.W.M., 1999. Late Campanian belemnite faunas from Liège-Limburg (NE Belgium, SE Netherlands). Belgian Geological Survey, Professional Paper 287: 1-31.

Keutgen, N. \& van der Tuuk, L.A, 1991. Belemnites from the Lower Maastrichtian of Limburg, Aachen and Liège. Mededelingen van de Rijks Geologische Dienst 44 (1990): 3-39.

King, C., 1981. The stratigraphy of the London Clay and associated deposits. Tertiary Research, Special Paper 6: 158 pp.

King, C., 1990. Eocene Stratigraphy of the Knokke Borehole (Belgium). In: Laga, P. \& Vandenberghe, N. (eds): The Knokke Well (11E/138) with a description of the Den Haan (22W/276) and Oostduinkerke (35/142) wells. Toelichtende Verhandelingen bij de Geologische en Mijnkaarten van België (Brussel) 29: 67-102.

Laenen, B., 1997. The Geochemical Signature of Relative Sea-level Cycles Recognized in the Boom Clay. Doctoral thesis K.U. Leuven (3 volumes): 523 pp.

Laenen, B., 1998. The geochemical signature of relative sea-level cycles recognized in the Boom Clay. Aardkundige Mededelingen (Leuven) 9: 61-82.

Laga, P., Louwye, S. \& Geets, S., 2002. Paleogene and Neogene lithostratigraphic units (Belgium). In: Bultynck, P. \& Dejonghe, L. (eds): Guide to a revised lithostratigraphic scale of Belgium. Geologica Belgica 4 (2001): 135-152.

Lagrou, D., Vandenberghe, N., Van Simaeys, S. \& Hus, J., this volume. Magnetostratigraphy and rock magnetism of the Boom Clay (Rupelian stratotype) in Belgium. Netherlands Journal of Geosciences.

Langenaeker, V., 2000. The Campine Basin. Stratigraphy, structural geology, coalification and hydrocarbon potential for the Devonian to Jurassic. Aardkundige Mededelingen (Leuven University Press) 10: $142 \mathrm{pp}+4$ maps.

Louwye, S., 2001. Dinoflagellate cysts and acritarchs from the Miocene Zonderschot Sands, Northern Belgium: stratigraphic significance and correlation with contiguous areas. Geologica Belgica 3 (2000): 55-65.

Louwye, S. \& Laga, P., 1998. Dinoflagellate cysts of the shallow marine Neogene succession in the Kalmthout well, northern Belgium. Bulletin of the Geological Society of Denmark 45: 73-86.

Louwye, S., De Coninck, J. \& Verniers, J., 1999. Dinoflagellate cyst stratigraphy and depositional history of Miocene and Lower Pliocene formations in northern Belgium (southern North Sea Basin). Geologie en Mijnbouw 78: 31-46.

Louwye, S., De Coninck, J. \& Verniers, J., 2000. Shallow marine Lower and Middle Miocene deposits at the southern margin of the North Sea Basin (northern Belgium): dinoflagellate cyst biostratigraphy and depositional history. Geological Magazine 137: 381-394.

Louwye, S., Head, M.J. \& De Schepper, S. (in press). Palaeoenvironment and dinoflagellate cyst stratigraphy of the Pliocene in northern Belgium at the southern margin of the North Sea Basin. Geological Magazine.

Mertens, J., Vandenberghe, N., Wouters, L. \& Sintubin, M. 2003. The origin and development of joints in the Boom Clay Formation (Rupelian) in Belgium. In: Van Rensbergen, P., Hillis, R.R., Maltman, A.J. \& Morley, C.K. (eds): Subsurface Sediment Mobilization. Geological Society of London, Special Publication 216: 309-321.

Michelsen, O., Thomsen, E., Danielsen, M., Heilmann-Clausen, C., Jordt, H. \& Laursen, G.V., 1998. Cenozoic sequence stratigraphy in the eastern North Sea. In: de Graciansky, P.-C., 
Hardenbol, J., Jacquin, T. \& Vail, P.R. (eds): Mesozoic and Cenozoic Sequence Stratigraphy of European Basins. Society for Sedimentary Geology (SEPM), Special Publication 60: 91-118.

Neal, J.E. 1996. A summary of Paleogene sequence stratigraphy in northwest Europe and the North Sea. In: Knox, R.W.O'B., Corfield, R.M. \& Dunay, R.E. (eds): Correlation of the Early Paleogene in Northwest Europe. Geological Society of London, Special Publication 101: 15-42.

Neal, J.E. \& Hardenbol, J., 1998. Introduction to the Paleogene In: de Graciansky, P.-C., Hardenbol J., Jacquin T. \& Vail, P.R. (eds): Mesozoic and Cenozoic Sequence Stratigraphy of European Basins. Society for Sedimentary Geology (SEPM), Special Publication 60: 87-90.

Neal, J.E., Stein, J.A. \& Gamber, J.H., 1998. Nested stratigraphic cycles and depositional systems of the Paleogene Central North Sea. In: de Graciansky, P.-C., Hardenbol, J., acquin, T. \& Vail, P.R. (eds): Mesozoic and Cenozoic Sequence Stratigraphy of European Basins. Society for Sedimentary Geology (SEPM), Special Publication 60: 261-288.

Nolf, D. \& Steurbaut, E., 1990. Excursion de l'A.G.B.P. en Belgique, du 24 au 26 Mai 1990. Première partie: Stratigraphie de l'Eocène en Flandre occidentale et dans les régions limitrophes. Bulletin d'Information des Géologues du Bassin de Paris, 27, 9-36.

Quesnel, F., Théveniaut, H., Voisin, L. \& Wyns, R., 2003. The 'Pierre de Stonne' and the 'Borne de fer' as main features of Meso-Cenozoic paleoweathering of the Upper Lorraine and Ardennian Thiérache areas. In: Quesnel, F. (ed): Paleoweathering and Paleosurfaces in the Ardenne-Eifel region. Géologie de la France No 1. Field trip guides: 11-28.

Robaszynski, F., Dhondt, A.V. \& Jagt, J.W.M., 2002. Cretaceous lithostratigraphic units (Belgium). In: Bultynck, P. \& Dejonghe, L. (eds): Guide to a revised lithostratigraphic scale of Belgium. Geologica Belgica (Brussel) 4: 121-134.

Rutot, A., 1883. Les phénomènes de la sédimentation marine étudiés dans leurs rapports avec la stratigraphie regionale. Bulletin du Musée Royal d'Histoire Naturelle de Belgique II: 64-78.

Saeys, R., Verheyen, A. \& Vandenberghe, N., this volume. A claymineral event in the earliest Priabonian of the North-Sea Basin? Netherlands Journal of Geosciences / Geologie en Mijnbouw.

Schiøler, P., Brinkhuis, H., Roncaglia, L. \& Wilson, G.J., 1997. Dinoflagellate biostratigraphy and sequence stratigraphy of the Type Maastrichtian (Upper Cretaceous), ENCI Quarry, The Netherlands. Marine Micropaleontology 31: 65-95.

Sintubin, M., Laga, P., Vandenberghe, N., Kenis, I. \& Dusar, M., 2001. Deformation features in Paleogene sands in the Hoegaarden area (Belgium). Geologica Belgica 3 (2000): 257-269.

Smith, T., De Wilde, B. \& Steurbaut, E., 2003. Terrestrial mammals from the base of the Lede Formation, Middle Eocene of Belgium. Abstracts Bultynck Meeting 22nd November 2003, Royal Belgian Institute Natural Sciences (Brussels): 18.

Spiegler, D., 2001. Bolboforma Biostratigraphy in the Neogene Glauconitic Sands of Belgium. Aardkundige Mededelingen (Leuven) 11: 61-67.

Steurbaut, E., 1998. High-resolution holostratigraphy of Middle Paleocene to Early Eocene strata in Belgium and adjacent areas. Palaeontographica A247: 91-156.

Steurbaut, E., De Coninck, J., Roche, E. \& Smith, T., 1999. The Dormaal Sands and the Paleocene/Eocene boundary in Belgium. Bulletin de la Société géologique de France 170: 217-227.

Vandenberghe, N., Laenen, B., Van Echelpoel, E. \& Lagrou, D., 1997. Cyclostratigraphy and climatic eustacy. Example of the Rupelian stratotype. Comptes Rendus de l'Académie des Sciences (Paris), Sciences de la Terre et des Planètes 325: 305-315.
Vandenberghe, N., Laga, P., Steurbaut, E., Hardenbol, J. \& Vail, P.R., 1998. Tertiary sequence stratigraphy at the southern border of the North Sea Basin in Belgium. In: de Graciansky, P.-C., Hardenbol, J., Jacquin, T. \& Vail, P.R. (eds): Mesozoic and Cenozoic Sequence Stratigraphy of European Basins. Society for Sedimentary Geology (SEPM), Special Publication 60: 119-154. Vandenberghe, N., Herman, J., Laga, P., Louwye, S., De Schepper, S., Vandenberghe, J., Bohncke, S. \& Konert, M., 2001. The stratigraphic position of a Pliocene tidal clay deposit at Grobbendonk (Antwerp province, Belgium). Geologica Belgica 3 (2000): 405-417.

Vandenberghe, N., Hager, H., van den Bosch, M., Verstraelen, A., Leroi, S., Steurbaut, E., Prüfert, J. \& Laga, P., 2001. Stratigraphical correlation by calibrated well logs in the Rupel Group between North Belgium, the Lower-Rhine area in Germany and Southern Limburg and the Achterhoek in The Netherlands. Aardkundige Mededelingen (Leuven) 11:69-84 + 15 figures.

Vandenberghe, N., Herman, J. \& Steurbaut, E., 2002. Detailed Analysis of the Rupelian Ru-1 Transgressive Surface in the Type Area (Belgium). In: Gürs, K. (ed): Northern European Cenozoic Stratigraphy. Proceedings of the 8th Biannual Meeting of the Regional Committees RCNNS/RCNPS (northern Paleogene and Neogene Stratigraphy). Landesamt für Natur und Umwelt des Landes Schleswig-Holstein (Flintbek): 67-81.

Vandenberghe, N., Brinkhuis, H. \& Steurbaut, E., 2003. The Eocene/Oligocene Boundary in the North Sea Area: A Sequence Stratigraphic Approach. In: Prothero, D.R., Ivany, L.C. \& Nesbitt, E.A. (eds): From Greenhouse to Icehouse.The Marine Eocene-Oligocene Transition. Columbia University Press (New York): 419-437.

Van Echelpoel, E. \& Weedon, G.P., 1990. Milankovitch cyclicity and the Boom Clay Formation: an Oligocene siliciclastic shelf sequence in Belgium. Geological Magazine 127: 599-604.

Van Simaeys, S., De Man, E., Vandenberghe, N., Brinkhuis, H. \& Steurbaut, E., 2004. Stratigraphic and palaeoenvironmental analysis of the Rupelian-Chattian transition in the type region: evidence from dinoflagellate cysts, foraminifera and calcareous nannofossils. Palaeogeography, Palaeoclimatology, Palaeoecology 208, 31-58.

Verheyen, A., 2003. Geofysische karakterisatie en correlatie van de Eoceen-Oligoceen overgangslagen in België. Licentiaatsverhandeling K.U. Leuven: 119 pp.

Vonhof, H.B. \& Smit, J., 1996. Strontium-isotope stratigraphy of the type Maastrichtian and the Cretaceous/Tertiary boundary in the Maastricht area (SE Netherlands). In: Brinkhuis, H. \& Smit, J. (eds): The Geulhemmerberg Cretaceous/Tertiary boundary section (Maastrichtian type area, SE Netherlands). Geologie en Mijnbouw 75: 275-282.

Wouters, L. \& Vandenberghe, N., 1994. Geologie van de Kempen. Een synthese. NIRAS (Nationale Instelling voor Radioactief Afval en Verrijkte Splijtstoffen) (Brussel): $208 \mathrm{pp}$.

Zachos, J., Pagani, M., Sloan, L.C., Thomas, E. \& Billups, K., 2001. Trends, Rhythms and Aberrations in Global Climates 65 Ma to present. Science 292: 686-693.

Zijlstra, J.J.P., 1994. Sedimentology of the Late Cretaceous and Early Tertiary (tuffaceous) chalk of northwest Europe. Geologica Ultraiectina 119:1-192. 